DJS Vol. 43 (1) (2021) - ISSN: 1012-5965 p. 97-114

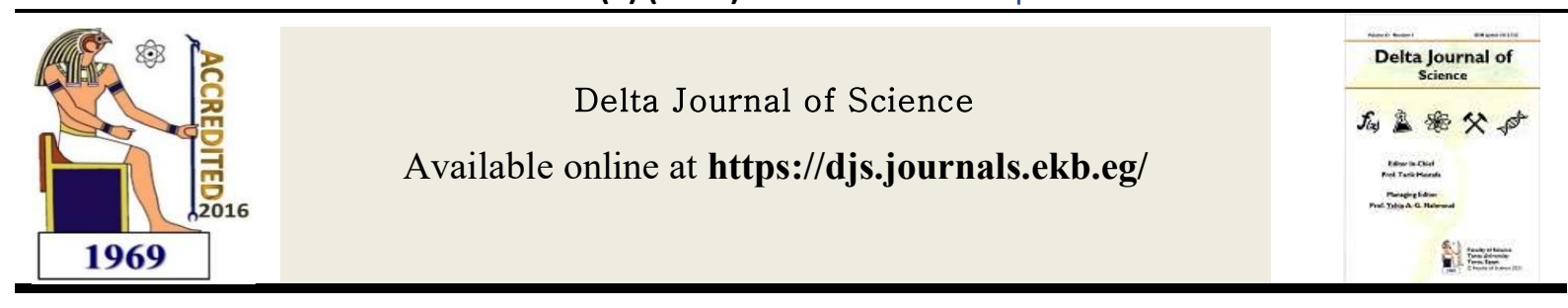

Research Article

GEOLOGY

\title{
Petrogenesis and tectonic implications of Seih Syn-tectonic gabbroic intrusion, South Sinai, Egypt: Insights from whole-rock geochemistry, mineral chemistry, and P-T estimate
}

\author{
Mohamed F. Ghoneim'; Mohamed Abu Anbar ${ }^{1, *}$; Dina H. Ramadan'; Ahmed E. Masoud ${ }^{1}$ \\ 1 Geology Department, Faculty of Science, Tanta University, Tanta, Egypt \\ *Corresponding author Mohamed Abu Anbar e-mail: mmanbar@Science.Tanta.edu.eg
}

\section{KEY WORDS}

Geothermobarometry,

Mineral Chemistry,

Wadi Seih, South

Sinai, Egypt, Arabian-

Nubian Shield

\begin{abstract}
The present work deals with the gabbroic intrusion in Wadi Seih area as a part of the Neoproterozoic Pan-African basement in the southwestern part of Sinai, Egypt. It comprises as small plutons intruded into Seih metamorphic belt. The intrusions comprise hornblende gabbros, anorthositic gabbros, and sometimes occur as coarse-grained gabbros (appenites). These plutons belong to what is known throughout Egypt as Younger Gabbros. The present study includes petrography, whole-rock geochemistry, mineral chemistry, and geothermobarometry. Geochemically, the gabbroic intrusions are derived from tholeiitic magma with minor calc-alkaline affinity. They have the chemical signature of subduction-related arc magmatism formed at an active convergent plate margin by $15-30 \%$ of partial melting of garnet lherzolite and to a minor extent of spinel-garnet lherzolite sources, modified by fluids related to a subducting slab. Mineral chemistry indicates that the gabbroic rocks crystallized at a pressure between 2.9 and $4.4 \mathrm{~kb}$ and a temperature between $590{ }^{\circ} \mathrm{C}$ and $700{ }^{\circ} \mathrm{C}$.
\end{abstract}

\section{Introduction}

The Seih Syn-tectonic gabbroic intrusion is one of the gabbroic intrusions in southwestern Sinai (Fig. 1). Gabbroic rocks in Egypt are considered as a key part of the Pan-African belt of Egypt and occur in two forms. The first is deformed, metamorphosed, and tectonically emplaced (ophiolitic gabbros) or magmatically intruded (metagabbro-diorite complex). The second, named younger gabbro, is undeformed, unmetamorphosed, layered in many areas, and was intruded before the post-tectonic granites but later than the molasse type sediment. The gabbroic rocks in Sinai are still controversial in terms of their origin, tectonic setting, and age. The intrusive gabbros have been studied in many localities in south Sinai and belong to intrusive layered younger gabbros (ElMettwaly 1992; El-Tokhi and Katta 1993; Essawy et al. 1997; Basta 1998; Takla et al., 2001; Abu Anbar, 2009; Abdel-Karim, 2013). Other authors (e.g., Hassanen, 1989; Higazy and El-Gammal, 1989; Lebda et al., 
2019) suggested that the gabbros in Sinai belong to metagabbro-diorite complexes.

The present work deals with the geology, petrology, mineral chemistry, and whole-rock chemistry of Seih gabbroic rocks in the south Sinai (Fig. 1.). The main objective of the present work is to explain the mineralogical and petrologic characteristics, magma type, tectonic setting, condition of crystallization, and petrogenesis of these gabbroic rocks.

\section{Geological background}

Regarding the metagabbro-diorite complex of south Sinai, most authors (ElSheshtawy, 1984; El-Metwally, 1986; Belasy, 1991; and Abdel-Karim, 1995) argue it has a younger age than gneisses and migmatites. El-Tokhi (1990) disagreed with them and considered it as old. Based on geochemical criteria, El-Metwally (1986) concluded that the metagabbro-diorite complex, north of Wadi Feiran, South Sinai, was derived from tholeiitic magma. Belasy (1991) recognized that the rock complex evolved from calc-alkaline to tholeiitic magma and evolved within the volcanic arc environment. Abdel-Karim (1995) concluded that the metagabbro-diorite complex, southwest Sinai, was derived from subalkaline magma in an island arc setting. Mehanna and Soliman (2000) mentioned that the metagabbro-diorite complex of Wadi El-Gofa area is equivalent to the syntectonic metagabbro of the Eastern Desert.

Furnes et al. (1985) reported that the Shahera gabbro-diorite complex (Kid area) is predominantly tholeiitic and showed both MORB and island arc affinity. Hassanen (1989) related the metagabbro-diorite complex in Wadi Kid to a transitional ocean floor environment of high K-tholeiitic gabbro and calc-alkaline quartz-diorite characteristic of the subduction zone. Hassanen (1989) indicated that the Melhega metagabbro-diorite complex in southeastern
Sinai originated from magmas related to a subduction zone in a transitional ocean floor to arc environment. Ghoneim et al. (1991) stated that the Shahera metagabbros are similar to non-orogenic gabbros and were crystallized from alkaline magma. Madbouli (1991) studied the gabbroic rocks of southern Sinai, especially El Mahash, El Bida, Feiran, Sa'al, and Melhega, and showed that these gabbroic masses exhibit chilled margins at their contact with the country rocks. The chilled margins are represented by fine-grained fresh gabbronorite and oxy hornblende gabbro, whereas the gabbroic masses are mainly oxy hornblende gabbro, olivine gabbro, pyroxene hornblende gabbro, leucogabbro, and gabbro-norite.

Basta (1998) studied the mineralogy and petrology of some gabbroic intrusions in the southern Sinai (e.g., Melhega, Sa'al, and Watier) and in the Eastern Desert. He concluded that these rocks were formed from calc-alkaline magma in an active continental margin setting. Higazy and ElGammal (1989) studied the petrography and geochemistry of the gabbros from the northwestern part of the basement rocks in Sinai and considered that the Nesryin gabbroic intrusion is related to the metagabbro-diorite complexes, whereas ElTokhi and Katta (1993) studied the intrusive gabbro-diorite complex around Wadi El Akhdar and Wadi Nesryin, and concluded that the gabbros were intrusive in nature, tholeiitic, and probably represented differentiated mantle-derived magma intruded into an island arc setting.

K-Ar dating of some metagabbrodiorite masses in southwest Sinai yields 794 $\mathrm{Ma}$ (time of emplacement and crystallization). The age range between 690 and $667 \mathrm{Ma}$ represents the thermal event (Abdel-Karim, 1995). The gabbroic rocks of Wadi Nesryin, southwest Sinai (southern part of the study area), are described as 


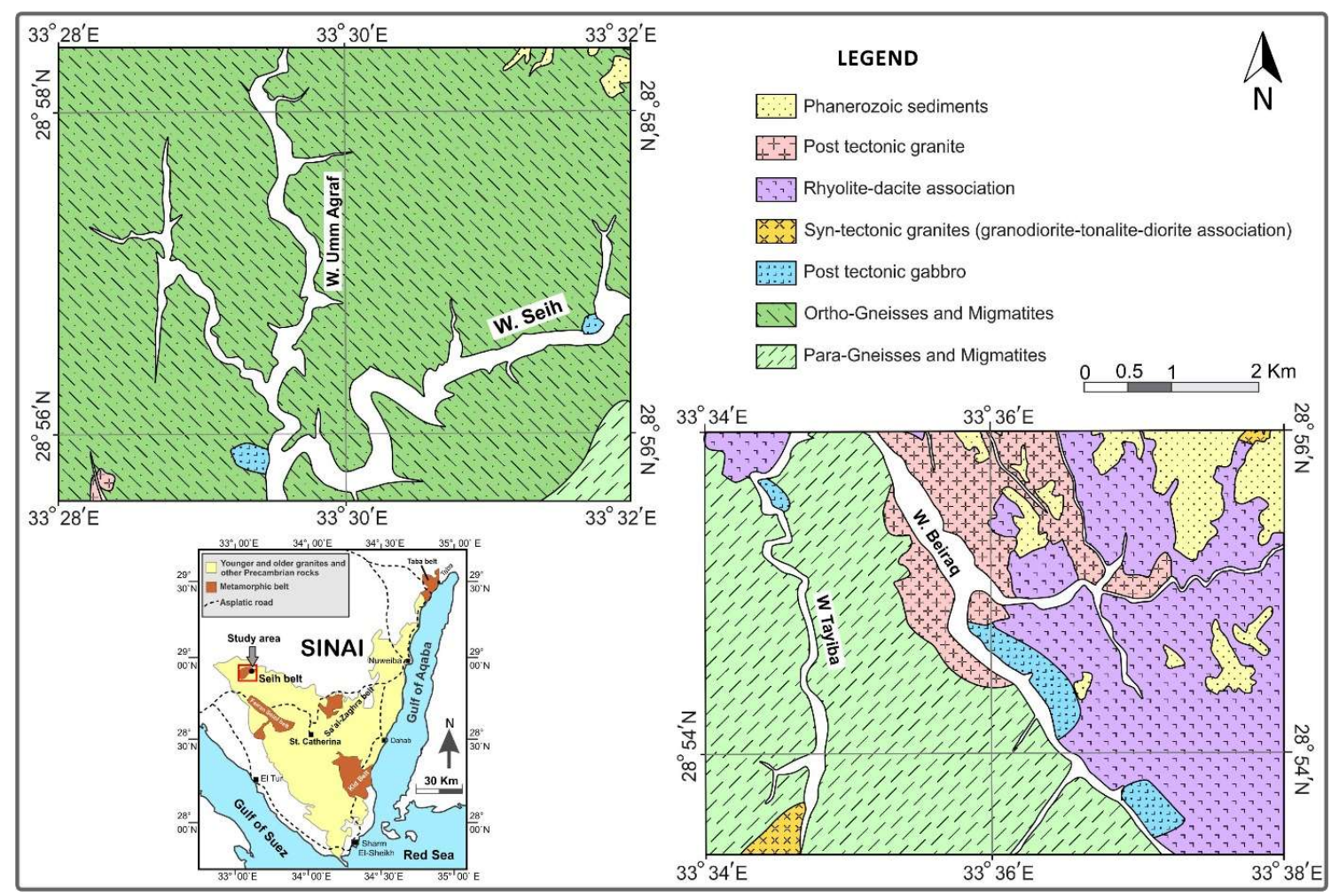

Fig. 1. Geological map of gabbroic intrusions in Seih area, South Sinai, Egypt.

coarse to medium-grained metagabbro, variably deformed, locally banded, hornblende, and olivine-bearing (EGSMA, 1994). Takla et al. (2001) concluded that most of the metagabbro-diorite complexes and the ophiolitic ultramafic rocks in Sinai belong to the group of younger gabbros and ultramafics.

Abu Anbar (2009) concluded that the Nesryin gabbroic intrusion has an island arc tholeiitic and volcanic arc signature. He concluded that the Nesryin gabbroic intrusion, emplaced at $617 \pm 19 \mathrm{Ma}$, is one of the mafic-ultramafic intrusions in the PanAfrican belt in southern Sinai related to the Egyptian younger gabbros. The Nesryin gabbroic intrusion is therefore not part of the older metagabbro-diorite complexes or the ophiolitic suite.

Abdel-Karim (2013) studied five minor intrusions of younger gabbros at Wadis Tweiba, Nakhil, Wadi Rahaba, Imliq, and El-Khamila in south Sinai. The geochemical characteristics of these gabbroic rocks indicate their derivation from two magma types (tholeiitic and calcalkaline). Both types are closely related in time and space, but with different geochemical trends. The tholeiitic younger gabbros at W. Tweiba, W. Rahaba, and Khamila areas are generally characterized by high $\mathrm{FeO}^{\mathrm{t}}, \mathrm{TiO}_{2}, \mathrm{MnO}$, and LILE (e.g., Zr, $\mathrm{Y}, \mathrm{Nb}$, Th, and LREE) contents as compared with the calc-alkaline younger gabbros. The calc-alkaline younger gabbros at Imliq and W. Nakhil areas are characterized by high contents of $\mathrm{SiO}_{2}, \mathrm{Al}_{2} \mathrm{O}_{3}, \mathrm{CaO}, \mathrm{Sr}$, and $\mathrm{U}$. The investigated gabbros of all localities have LREE enrichment; HREE depletion and a small positive $\mathrm{Eu}$ anomaly suggest their moderate differentiation. The existence of the present two magma types reveals a heterogeneous mantle (or upper mantlelower crust) source. They were mostly generated and emplaced in the continental crust and tend to be formed by a transitional compression-extension regime dominated by the final arc stage to the active continental margin. 
Lebda et al., 2019 studied some older granite (OG) and metagabbro-diorite complex (MG) outcrops pertaining to the island arc regime in south Sinai. Three selected areas via Nesryin, El-FringaMinader, and Shahera outcrops are selected as a case example. The OG compositions are tonalite and granodiorite, whereas $\mathrm{MG}$ constitutes hornblende-metagabbros, hornblende-leucogabbro, and diorite. Geochemically, the OG rocks are peraluminous, calc-alkaline, and I-type and belong to syn-collision volcanic arc. The MG varieties exhibit transitional calcalkaline/tholeiite magma types and are comparable to rocks of island arc setting.

\section{Geological setting and field relations}

The gabbroic rock intrusion of Wadi Seih occurs in the northern part of the Arabian shield in southern Sinai. It forms as rounded masses at Wadi Naba in the southwestern part of Seih area and also occurs as small masses at the intersection between Wadi Seih and Wadi Umm Agraf, Wadi Tayeba, Wadi Seih, and at Wadi Baraq (Fig. 1). These rocks are coarse-grained and range in size from $1 \mathrm{~mm}$ to $1 \mathrm{~cm}$. Gabbro in Wadi Naba, in the western part of Wadi Seih, is intruded by post-tectonic granites of Gabal Ataitir El Dehami. The gabbroic intrusion exhibits sharp intrusive contacts with the surrounding gneisses and sends offshoots and apophyses into the gneisses (Fig. 2a). The present gabbros contain a lot of enclaves from the gneisses in different forms near the contact, sometimes in irregular forms (Fig. 2b) and as sheets from gneisses (Fig. 2c). It also contains small quartz veins $(2-3 \mathrm{~cm})$ (Fig. 2d). The gabbroic outcrop in Wadi Tayeba shows magmatic layering from leuco and melagabbro (Fig. 2e). Also, it shows anorthositic veins in random distribution within the gabbroic mass (Fig. 2f).

\section{Petrography}

Petrographic compositions of studied syn-tectonic gabbro are mainly hornblende gabbro and anorthosite gabbro. The hornblende gabbro is medium- to coarsegrained with a light greyish color, composed mainly of plagioclase $\left(\mathrm{An}_{35-70)}\right.$ and hornblende. Accessory minerals include iron oxides, magnetite, apatite, and sphene. The rock shows hypidiomorphic, ophitic, and sub-ophitic textures (Figs. 3.a, b, and d). Plagioclase $\left(\mathrm{An}_{35-70}\right)$ occurs as twinned subhedral crystals enclosed by hornblende, forming ophitic and sub-ophitic textures. It is commonly twinned. Crystals are partially altered to sericite. Hornblende occurs either as euhedral or subhedral prismatic crystals and is partly twinned (Fig. 3e). It is strongly pleochroic with $\mathrm{X}=$ yellowish-brown, $\mathrm{Y}=$ pale brown, and $Z=$ dark brown. Quartz occupies the interstices between plagioclase and hornblende and commonly corrodes their boundaries. Apatite occurs in association with plagioclase with moderate relief and first-order grey interference color. Sphene occurs as anhedral grains. Iron oxides are represented by anhedral grains of magnetite, which sometimes form clusters or scattered ones.

Anorthosite gabbro is a coarse-grained igneous rock. It is composed mainly of anorthite $(>90 \%)$ with a minimal amount of pyroxene, and there is hornblende (Fig. 3f). Iron oxides occur as accessory minerals.

\section{Whole-rock geochemistry}

Geochemical analyses were carried out at the Earth Sciences Department, Ferrara University, Italy. Major elements and $\mathrm{Pb}, \mathrm{Zn}, \mathrm{Ni}, \mathrm{Co}, \mathrm{Cr}, \mathrm{V}, \mathrm{Rb}, \mathrm{Sr}, \mathrm{Ba}, \mathrm{Nb}$, $\mathrm{Zr}$, and $\mathrm{Y}$ were determined by $\mathrm{X}$-ray fluorescence spectrometry (XRF) on pressed powder pellets using an ARL Advant-XP spectrometer, following the full matrix 

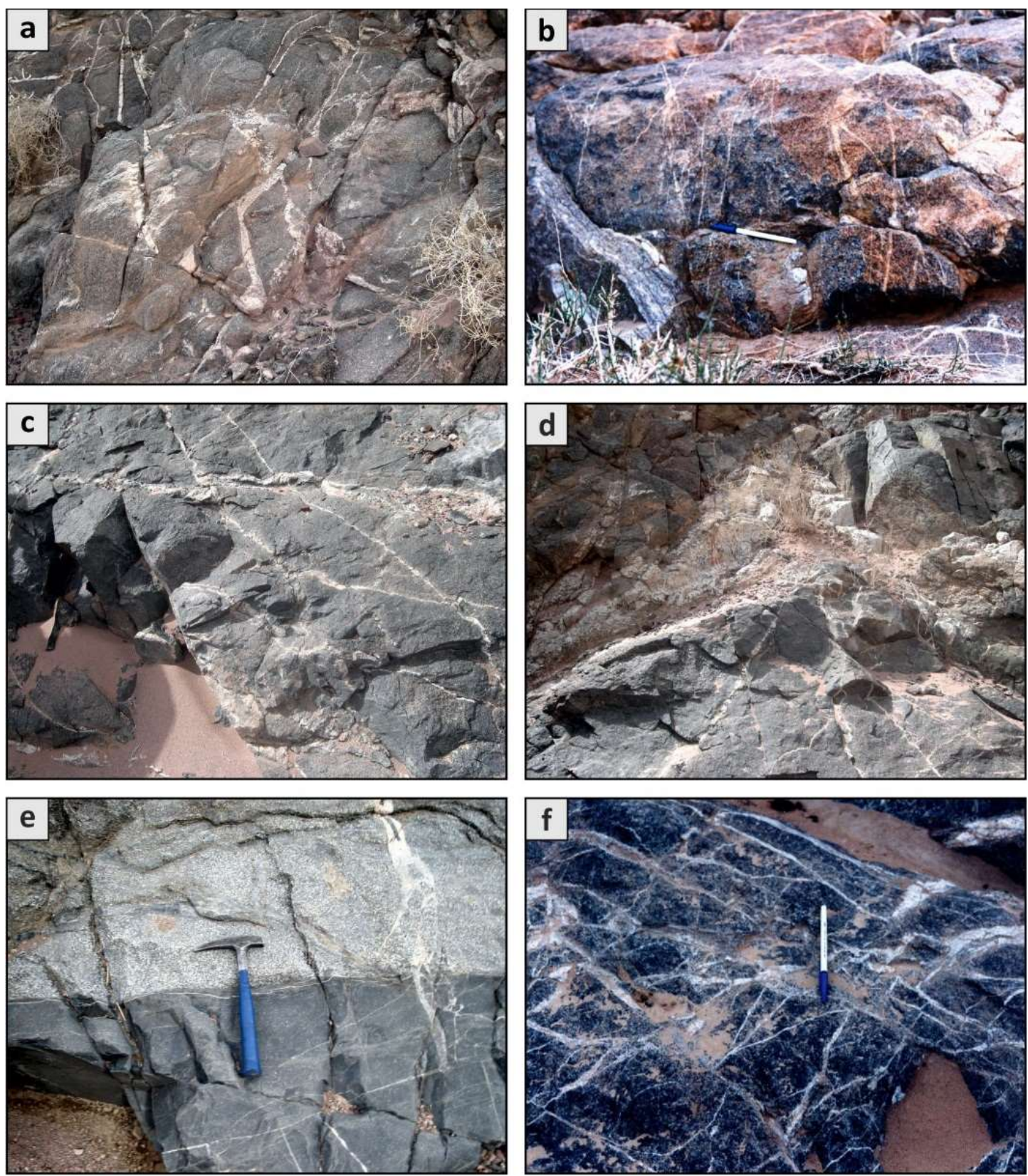

Fig. 2. Field photograph of syn-tectonic gabbro. (a) Sharp contact between gneisses and syntectonic gabbro, (b) Enclaves of gneisses inside syn-tectonic gabbro, (c) Gneisses occur as sheets inside the syn-tectonic gabbro, (d) Small quartz veins inside syn-tectonic gabbro, (e) Magmatic layering from leuco and melagabbro, (f) Anorthositic veins in the gabbroic mass.

correction method proposed by Lachance and Traill (1966). Accuracy is generally less than $2 \%$ for major oxides and less than $5 \%$ for trace element determinations. Detection limits for trace elements are in the few ppm range. Replicate analyses for some trace elements gave a precision better than 5\%. Loss on ignition (LOI) was determined gravimetrically after heating the sample powder to $1,000{ }^{\circ} \mathrm{C}$ for $1 \mathrm{~h}$.
The geochemistry of the Syn tectonic gabbros is based on five representative samples from Wadi Seih (E78, E88, SA7, SA25, and SA3A). Data of El-Fringa Minader gabbro after Lebda et al. (2019) are used for comparison. Table 1 represents major and trace element composition as well as geochemical parameters of the present gabbros. 

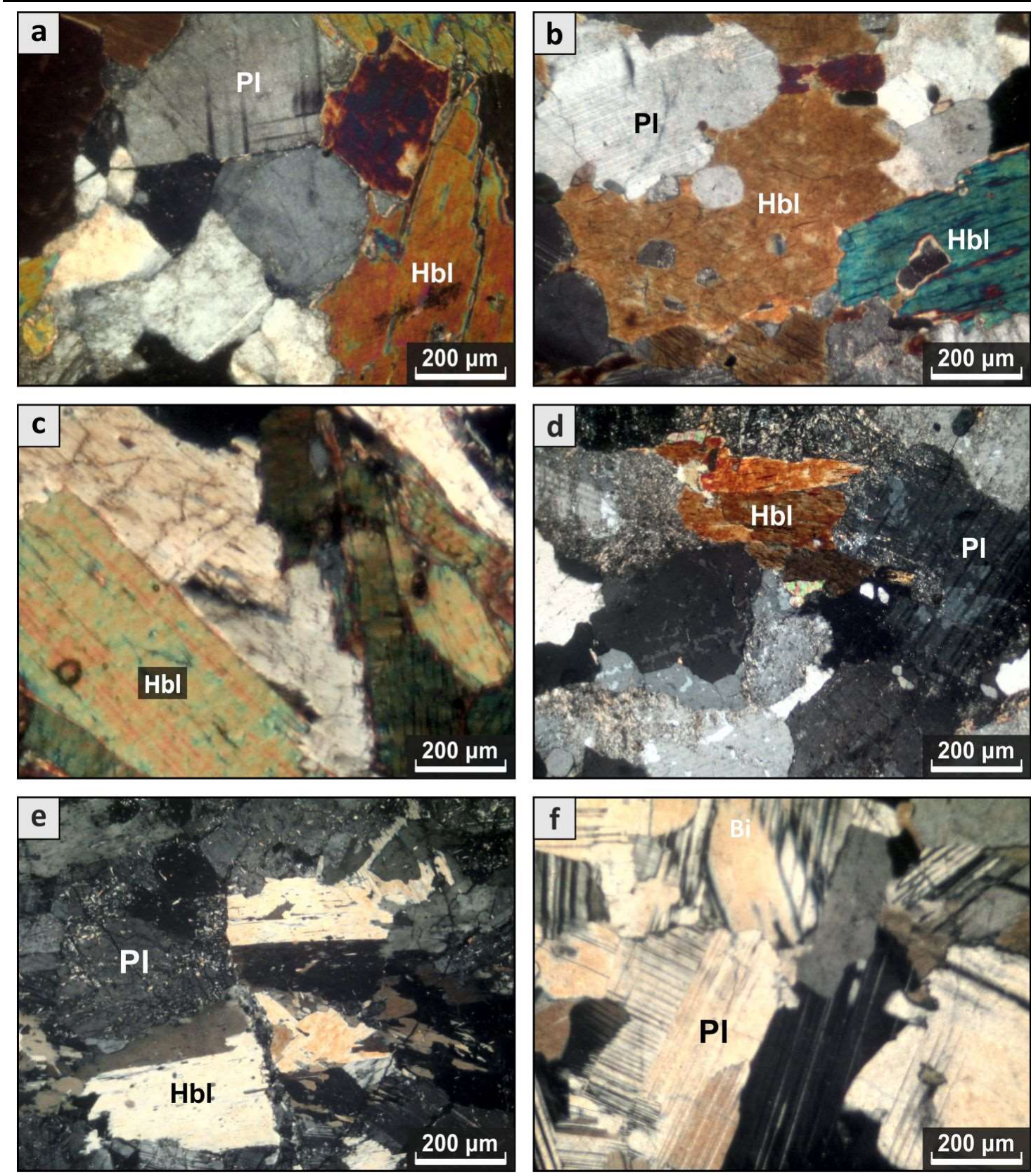

Fig. 3. Cross polarized (XPL) photomicrographs of gabbro. (a) hornblende-gabbro showing large plagioclase crystals surrounded by hornblende, (b) hornblende-gabbro showing ophitic texture, (c) hornblende gabbro, (d) hornblende gabbro showing slightly altered plagioclase, (e) hornblende gabbro showing Carlsbad and Baveno twining in hornblende, and (f) anorthosite, which composed mainly of plagioclase. Symbols inside the photo: $\mathrm{Hbl}=$ Hornblende, $\mathrm{Pl}=$ Plagioclase.

\subsection{Major oxides and trace element compositions}

Major oxides such as $\mathrm{SiO}_{2}$ ranges from (44.13 wt. \% to $48.76 \mathrm{wt} . \%$ ) and $\mathrm{TiO}_{2}$ ranges from $(0.24$ to 1.48 wt. $\%) . \mathrm{Al}_{2} \mathrm{O}_{3}$ ranges from (11.27 to 17.19 wt.\%), whereas $\mathrm{Fe}_{2} \mathrm{O}_{3}$ shows a range from (5.68 to 14.59 wt.\%). $\mathrm{MnO}$ ranges from (0.12 to $0.17 \mathrm{wt} \%), \mathrm{MgO}$ ranges from (6.67 to 14.58 wt.\%), $\mathrm{CaO}$ ranges from (1.04 to 2.33 wt.\%), and $\mathrm{K}_{2} \mathrm{O}$ ranges from ( 0.37 to $1.52 \mathrm{wt} . \%)$.

Trace elements are widely varied in their concentrations among the samples. The most variable transition metals include, $\mathrm{Cr}$ ranges from (36.6 ppm to $369.8 \mathrm{ppm}$ ), $\mathrm{Ni}$ (13.2 ppm to $166.1 \mathrm{ppm}), \mathrm{V}$ (110.5 ppm to 
$286.1 \mathrm{ppm}), \mathrm{Sc}$ (29.7 ppm to $47.5 \mathrm{ppm})$, Co (37.6 ppm to $58.9 \mathrm{ppm})$ and $\mathrm{Ga}(2.1 \mathrm{ppm}$ to $13.19 \mathrm{ppm})$. The sample E88 has the highest ppm value for $\mathrm{Cr}, \mathrm{Ni}, \mathrm{Co}$, and $\mathrm{Sc}$, while $\mathrm{SA} 7$ has the lowest comparative values.
Chalcophile elements, including $\mathrm{Cu}$ and $\mathrm{Zn}$, are also varied. Copper ranges from (12.3 ppm to $121.6 \mathrm{ppm}$ ) and $\mathrm{Zn}$ ranges from (35.5 ppm to $132.1 \mathrm{ppm})$.

Table 1. Chemical analyses of gabbroic rocks.

\begin{tabular}{|c|c|c|c|c|c|c|c|c|c|c|c|c|}
\hline \multirow{2}{*}{\begin{tabular}{|l} 
Rock unit \\
Oxides/ \\
Sample.No
\end{tabular}} & \multicolumn{6}{|c|}{ Wadi Seih syn-tectonic gabbro } & \multicolumn{6}{|c|}{ El-Fringa-Minader gabbro } \\
\hline & E78 & E88 & SA7 & SA25 & SA3A & Average & N22 & N30 & N31 & N33 & N34 & Average \\
\hline $\mathrm{SiO} 2$ & 47.11 & 48.09 & 48.76 & 44.13 & 47.33 & 47.0849 & 51.8 & 56.01 & 54.13 & 57 & 58.08 & 55.404 \\
\hline $\mathrm{TiO} 2$ & 1.356 & 0.272 & 0.243 & 1.481 & 0.303 & 0.73119 & 1.8 & 1.5 & 1.3 & 0.9 & 0.49 & 1.198 \\
\hline AL2O3 & 11.27 & 15.75 & 15.91 & 17 & 17.19 & 15.4241 & 15.5 & 16.28 & 16.79 & 17.8 & 16.81 & 16.636 \\
\hline Fe2O3tot & 11.22 & 7.075 & 5.68 & 14.59 & 7.914 & 9.29571 & 12.1 & 8.48 & 7.25 & 10.2 & 7.67 & 9.14 \\
\hline $\mathrm{MnO}$ & 0.163 & 0.142 & 0.124 & 0.169 & 0.126 & 0.14485 & 0 & 0.14 & 0.13 & 0 & 0.11 & 0.076 \\
\hline $\mathrm{MgO}$ & 14.58 & 13.46 & 13.44 & 6.666 & 11.27 & 11.8841 & 2.1 & 5.4 & 8 & 2.8 & 6 & 4.86 \\
\hline $\mathrm{CaO}$ & 10.34 & 11.34 & 12.57 & 10.23 & 12.91 & 11.48 & 10 & 8.44 & 8.4 & 6.7 & 7 & 8.108 \\
\hline $\mathrm{Na} 2 \mathrm{O}$ & 1.694 & 1.098 & 1.039 & 2.329 & 1.407 & 1.51349 & 4.3 & 0.94 & 1.08 & 1.2 & 1.89 & 1.882 \\
\hline K2O & 0.804 & 0.537 & 0.487 & 1.522 & 0.371 & 0.7442 & 1.3 & 0.51 & 0.66 & 1.6 & 1.17 & 1.048 \\
\hline P2O5 & 0.188 & 0.016 & 0.013 & 0.732 & 0.029 & 0.19554 & 0.5 & 0.52 & 0.63 & 0.5 & 0.16 & 0.462 \\
\hline LOI & 1.27 & 2.21 & 1.73 & 1.15 & 1.15 & 1.502 & & & & & & \\
\hline Total & 100 & 100 & 100 & 100 & 100 & 100 & 99.4 & 98.22 & 98.37 & 98.7 & 99.38 & 98.814 \\
\hline \multicolumn{13}{|c|}{ Trace elments } \\
\hline $\mathrm{Ba}$ & 184.4 & 109.7 & 57.7 & 374.2 & 59.76 & \begin{tabular}{|l|}
157.168 \\
\end{tabular} & 2585 & 565 & 495 & 469 & 487 & 920.2 \\
\hline $\mathrm{Ce}$ & nd & nd & nd & nd & nd & 0 & nd & nd & nd & nd & nd & 0 \\
\hline Co & 58.86 & 43.34 & 37.61 & 39.42 & 48.36 & 45.5159 & 13 & 48 & 47 & 37 & 38 & 36.6 \\
\hline $\mathrm{Cr}$ & 369.8 & 105.7 & 36.59 & 91.52 & 131.1 & 146.928 & 125 & 77 & 196 & 52 & 77 & 105.4 \\
\hline La & 16.82 & 6.746 & nd & 14.2 & 4.752 & 8.50495 & nd & nd & nd & nd & nd & 0 \\
\hline $\mathrm{Nb}$ & 5.368 & nd & nd & 0.374 & nd & 1.14834 & 20 & 2 & 12 & 5 & 8 & 9.4 \\
\hline $\mathrm{Ni}$ & 166.1 & 44.7 & 13.19 & 15.32 & 31.08 & 54.0733 & 41 & 29 & 129 & 18 & 30 & 49.4 \\
\hline $\mathrm{Pb}$ & nd & nd & 3.472 & 5.68 & nd & 1.83029 & 36 & 15 & 15 & 15 & 17 & 19.6 \\
\hline $\mathrm{Rb}$ & 6.344 & 10.78 & 14.19 & 48.05 & 1.865 & 16.2456 & 27 & 4 & 27 & 24 & 17 & 19.8 \\
\hline $\mathrm{Sr}$ & 454.7 & 617.8 & 694.5 & 973.9 & 691.2 & 686.427 & 501 & 621 & 490 & 805 & 783 & 640 \\
\hline Th & 0.288 & nd & nd & 1.051 & nd & 0.26788 & nd & nd & nd & nd & nd & 0 \\
\hline V & 254.8 & 117.2 & 110.5 & 286.1 & 116.7 & 177.049 & 105 & 277 & 292 & 210 & 221 & 221 \\
\hline Y & 22.39 & 6.999 & 6.334 & 25.16 & 6.367 & 13.4503 & 4 & 16 & 13 & 22 & 39 & 18.8 \\
\hline $\mathrm{Zn}$ & 89.32 & 35.49 & 38.49 & 132.1 & 45.1 & 68.0938 & 63 & 119 & 109 & 93 & 176 & 112 \\
\hline $\mathrm{Zr}$ & 60.22 & 3.24 & nd & 72.19 & 7.415 & 28.6118 & 49 & 105 & 88 & 180 & 262 & 136.8 \\
\hline $\mathrm{Cu}$ & 121.6 & 33.48 & 62.72 & 71.89 & 12.28 & 60.3837 & 65 & 54 & 72 & 37 & 43 & 54.2 \\
\hline $\mathrm{Ga}$ & 7.293 & 2.662 & 2.099 & 13.95 & 2.323 & 5.66545 & 4 & 22 & 17 & 21 & 20 & 16.8 \\
\hline $\mathrm{Nd}$ & nd & nd & nd & 1.03 & nd & 0.20609 & nd & nd & nd & nd & nd & nd \\
\hline$S$ & nd & nd & 206 & nd & nd & 41.1953 & nd & nd & nd & nd & nd & nd \\
\hline $\mathrm{Sc}$ & 47.55 & 34.65 & 40.26 & 29.67 & 30.95 & 36.6145 & nd & nd & nd & nd & nd & nd \\
\hline \multicolumn{13}{|l|}{ CIPW Norm } \\
\hline Q & 0 & 0 & 0 & 0 & 0 & & & & & & & \\
\hline Or (KAS6) & 4.79 & 3.27 & 2.95 & 9.1 & 2.21 & & & & & & & \\
\hline Ab (NAS6) & 14.47 & 9.51 & 8.95 & 19.92 & 12.06 & & & & & & & \\
\hline An (CAS2) & 21.04 & 37.22 & 37.91 & 31.76 & 39.89 & & & & & & & \\
\hline$C(A)$ & 0 & 0 & 0 & 0 & 0 & & & & & & & \\
\hline Di wo(CS) & 12.44 & 8.44 & 10.66 & 6.38 & 10.33 & & & & & & & \\
\hline Di en(MS) & 10.73 & 7.28 & 9.19 & 5.5 & 8.91 & & & & & & & \\
\hline $\mathrm{Di} \mathrm{fs}(\mathrm{FS})$ & 0 & 0 & 0 & 0 & 0 & & & & & & & \\
\hline Hy en(MS) & 16.21 & 25.31 & 22.26 & 4.51 & 14.59 & & & & & & & \\
\hline Hy fs(FS) & 0 & 0 & 0 & 0 & 0 & & & & & & & \\
\hline $\mathrm{Ol}$ fo(M2S) & 6.99 & 1.28 & 1.92 & 4.81 & 3.5 & & & & & & & \\
\hline $\mathrm{Mt}(\mathrm{FF})$ & 0.53 & 0.47 & 0.4 & 0.56 & 0.43 & & & & & & & \\
\hline $\mathrm{He}(\mathrm{F})$ & 11 & 6.92 & 5.51 & 14.37 & 7.71 & & & & & & & \\
\hline $\mathrm{Ap}(\mathrm{CP})$ & 0.42 & 0.04 & 0.02 & 1.61 & 0.07 & & & & & & & \\
\hline Totals & 98.62 & 99.73 & 99.76 & 98.51 & 99.7 & & & & & & & \\
\hline
\end{tabular}

Data of El-Fringa-Minader gabbro after Lebda et al., 2019. 
Considering the large ion lithophile elements (LILEs), Ba ranges from (57.7 ppm to $374.2 \mathrm{ppm}$ ), Sr from (454.7 to $973.9 \mathrm{ppm}$ ), and $\mathrm{Rb}$ from (1.9 ppm to $48.1 \mathrm{ppm}$ ). As for the high field strength elements (HFSEs), $\mathrm{Zr}$ ranges between (3.2 ppm to $72.2 \mathrm{ppm}$ ) (one sample not detected), $\mathrm{Nb}$ content is $(0.4 \mathrm{ppm}$ to $5.4 \mathrm{ppm}$ ) (3 samples are not detected), Th is $(0.3 \mathrm{ppm}$ to $1.1 \mathrm{ppm})$ (3 samples not detected), and $\mathrm{Y}$ composition ranges between (6.3 ppm to $25.2 \mathrm{ppm})$. With respect to the rare earth elements (REEs), Ce is not detected, $\mathrm{La}$ is (4.8 ppm to $16.8 \mathrm{ppm}$ ) (one sample not detected), and $\mathrm{Nd}$ one sample only (SA25) reported $1 \mathrm{ppm}$.

\subsection{Spider diagram}

The behavior of trace elements is commonly illustrated by normalized diagrams. The present data are normalized to MORB (Sun and McDonough, 1989) and compared with gabbro of El-Fringa-Minader South Sinai, Egypt (Lebda et al., 2019), as shown in (Fig. 4a). It is clear from the figure that both Wadi Seih syn-tectonic gabbro and El-Fringa-Minader gabbro show similarities in their depletion of ( $\mathrm{Zn}, \mathrm{Cr}$, and $\mathrm{Ni})$ and enrichment of ( $\mathrm{Ba}, \mathrm{Rb}, \mathrm{Th}, \mathrm{Pb}$, and $\mathrm{Sr})$. In contrast, El-Fringa-Minader gabbro is relatively enriched in $\mathrm{Nb}, \mathrm{Zr}$, and $\mathrm{Y}$ compared to Wadi Seih syn-tectonic gabbro, which is depleted.

\subsection{Chemical classification, Magma type and Tectonic setting}

$\mathrm{SiO}_{2}$ versus $\left(\mathrm{Na}_{2} \mathrm{O}+\mathrm{K}_{2} \mathrm{O}\right)$ diagram (Cox et al., 1979) and (Wilson, 1989 and 1985) (Fig. 4b) is used for the nomenclature of the present syn-tectonic gabbro. The studied samples are plotted in gabbro field. The recognition of the magma type, its chemical nature, and its behavior on differentiation help to elucidate the tectonic setting of the present syn-tectonic gabbro. On the $\mathrm{SiO}_{2}$ versus $\left(\mathrm{Na}_{2} \mathrm{O}+\mathrm{K}_{2} \mathrm{O}\right)$ diagram (Fig. 4b) of (Cox et al.,1979) and (Kuno,
1968) diagram (Fig. 4.c) Wadi Seih syntectonic gabbro and El-Fringa-Minader gabbro fall within the subalkaline field except one sample lies in the alkaline field. Many diagrams are used to distinguish between the tholeiitic and calc-alkaline series.AFM (Fig. 4d) diagram was suggested by (Irvine and Baragar, 1971). The plotted data on this diagram clarifies the transitional nature (merging between calc-alkaline and tholeiite nature) for both of Wadi Seih syntectonic gabbro and El-Fringa-Minader gabbro. The Zr vs. Y discrimination diagram (Ross and Bédard, 2009) suggests that the syn-tectonic gabbro of Wadi Seih area belongs to the tholeiitic to transitional series, whereas El-Fringa-Minader gabbro belongs to the calc-alkaline magma series (Fig.4e).

The tectonic setting of the studied syntectonic gabbro is depicted in published diagrams. The $\mathrm{FeO}_{\text {tot }}-\mathrm{MgO}-\mathrm{Al}_{2} \mathrm{O}_{3}$ ternary diagram proposed by (Pearce et al., 1977) is commonly used to discriminate between different tectonic settings of similar rocks. On this diagram, 4 samples of the Wadi Seih syn-tectonic gabbro fall into the mid-ocean ridge basalt field (MORB), and one sample falls into the continental field (Fig. 4f). The comparative rocks of El-Fringa-Minader gabbro, four samples lie in the island and active continental margin and one sample lies in the spreading center island (EMORB) field as in (Fig. 4f).

\section{Mineral Chemistry}

About 25 single-point analyses were performed using an electron microprobe at the Institute of Geological Sciences, Wroclaw University, Poland, for some selected minerals (amphibole, feldspars, chlorite, biotite, and some Fe-Ti oxides). The chemistry of analyzed minerals was used to give important information about the chemical features of the magma source, tectonic setting, and P-T condition of crystallization. 

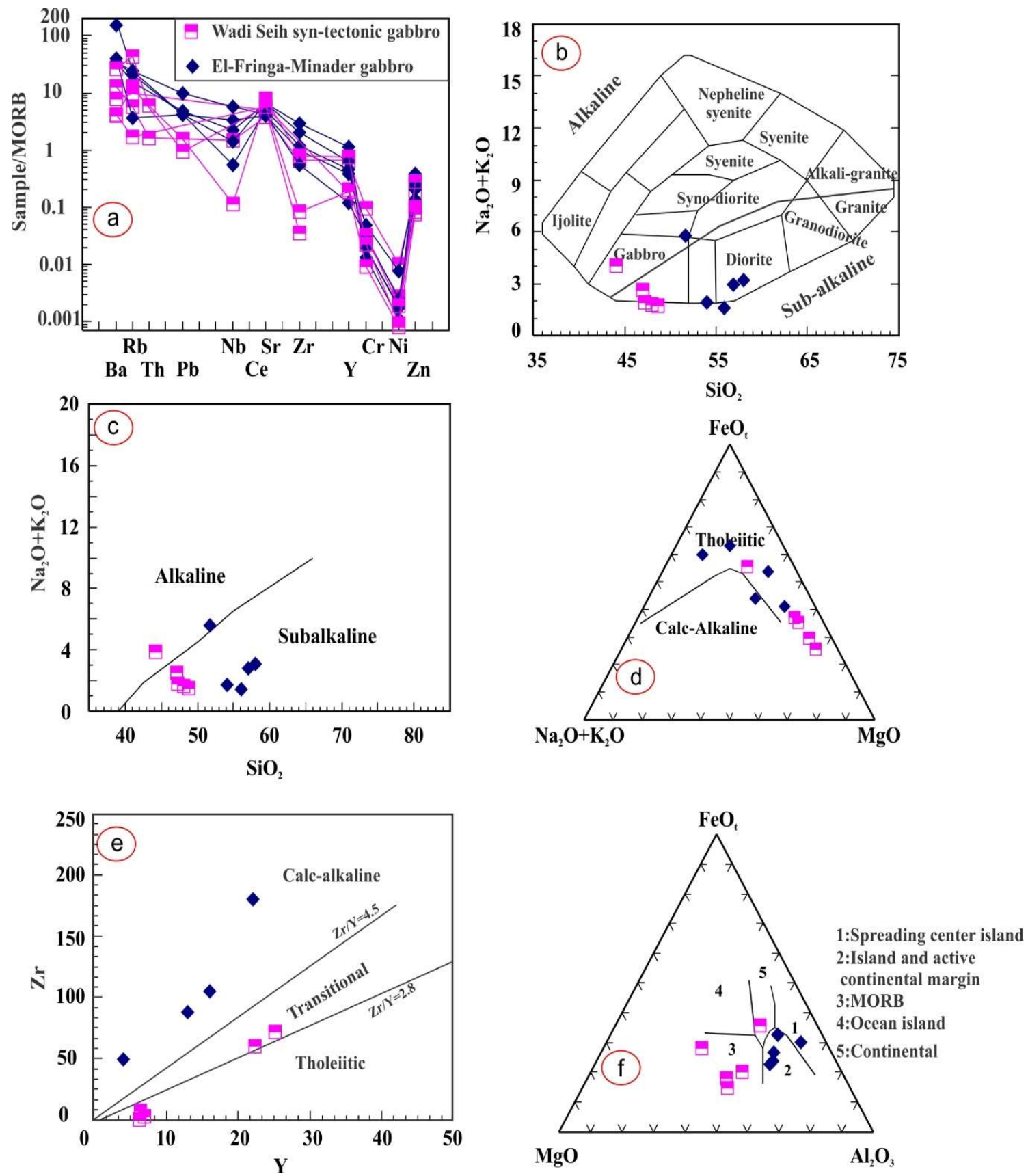

Fig.4. (a) Spider diagram for MORB - normalized trace elements of studied syn-tectonic gabbro. Normalization value after (Sun and McDonough 1989). El-Fringa-Minader gabbro data (Lebda et al., 2019) are plotted for comparison, (b) TAS diagram for the nomenclature of the studied syn-tectonic gabbro after (Cox et al., 1979 adopted by Wilson, 1989), (c) $\mathrm{SiO}_{2}$ vs. $\left(\mathrm{Na}_{2} \mathrm{O}+\mathrm{K}_{2} \mathrm{O}\right)$ diagram (after Kuno, 1968) for the studied gabbro, (d) AFM ternary diagram tholeiitic and calc alkaline after (Irvine and Baragar ,1971), (e) Zr-Y classification diagram for magma series (Ross and Bédard, 2009), and (f) ) The FeOt-MgO-Al2O3 ternary diagram, (Pearce et al., 1977).

\subsection{Amphibole}

The main objective of the present study is to estimate the variation in the chemical composition of the amphiboles to determine their nomenclature and throw

formation. Electron microprobe analyses for about 9 single points of the amphibole minerals and their chemical formulae based on 23 oxygen atoms are listed in (Table 2). 
Generally, amphiboles are classified according to the recommendations of the International Mineralogical Association (I.M.A). These were compiled by Leake (1978), Rock and Leake (1984), and Leake et al. (1997) as iron-magnesium-manganese group, calcic group, sodic-calcic group, and Alkali group. Accordingly, in the $\mathrm{BNa}$ versus $\mathrm{BCa}+\mathrm{BNa}$ diagram, the amphiboles of syn-tectonic gabbro are grouped as calcic amphibole group (Fig. 5a). The amphiboles of syn-tectonic gabbro are classified chiefly as magnesio-hornblende except for one sample located at the boundary between magnesio-hornblende and tschermakite hornblende (Fig. 5b).
The composition of amphibole minerals can be used to determine the geochemical affinity and tectonic setting of the parent magma. The studied syn-tectonic gabbro falls within the sub alkaline field (Fig. 5c) on the diagram of Molina et al. (2009).

\subsection{Biotite}

A total of 6 single points microprobe analyses were performed from syn-tectonic gabbro (sample E78). EMPA analyses of biotite minerals and their chemical formulae are calculated on the basis of 24 oxygen atoms are listed in (Table 3 ).

$\mathrm{On} \mathrm{Fe} /\left(\mathrm{Fe}+\mathrm{Mg}\right.$ ) vs. $\mathrm{Al}^{\mathrm{IV}}$ diagram (Fig. 5d) for biotite nomenclature of syn-tectonic

Table 2. Microprobe analyses and structural formulae of amphiboles.

\begin{tabular}{|c|c|c|c|c|c|c|c|c|c|}
\hline Sample & $\begin{array}{c}\text { E78- } \\
\text { iaa }\end{array}$ & $\begin{array}{c}\text { E78- } \\
\text { iab }\end{array}$ & $\begin{array}{c}\text { E78- } \\
\text { iac }\end{array}$ & $\begin{array}{l}\text { E78- } \\
\text { iad }\end{array}$ & $\begin{array}{c}\text { SA3A- } \\
\text { jaa }\end{array}$ & $\begin{array}{c}\text { SA3A- } \\
\text { jab }\end{array}$ & $\begin{array}{c}\text { SA3A- } \\
\text { jac }\end{array}$ & $\begin{array}{c}\text { SA3A- } \\
\text { jad }\end{array}$ & $\begin{array}{c}\text { SA3A- } \\
\text { jae }\end{array}$ \\
\hline core/rim & $\mathrm{c}$ & $\mathrm{r}$ & $\mathrm{c}$ & $\mathrm{r}$ & $\mathrm{c}$ & $\mathrm{r}$ & $\mathrm{c}$ & $r$ & $\mathrm{c}$ \\
\hline $\mathrm{SiO} 2$ & 44.55 & 46.39 & 47.46 & 48.44 & 49.33 & 49.02 & 47.75 & 50.49 & 49.52 \\
\hline $\mathrm{TiO} 2$ & 1.15 & 1.17 & 1.00 & 0.84 & 0.49 & 0.48 & 0.38 & 0.55 & 0.35 \\
\hline $\mathrm{Al} 2 \mathrm{O} 3$ & 12.09 & 10.16 & 8.44 & 8.25 & 7.92 & 9.26 & 8.22 & 7.07 & 7.91 \\
\hline $\mathrm{Fe} 2 \mathrm{O} 3$ & 4.06 & 0.89 & 2.28 & 2.29 & 4.64 & 3.42 & 3.91 & 3.96 & 3.92 \\
\hline $\mathrm{FeO}$ & 8.12 & 10.59 & 8.81 & 8.94 & 6.87 & 7.59 & 7.35 & 8.11 & 6.81 \\
\hline $\mathrm{MnO}$ & 0.19 & 0.21 & 0.25 & 0.21 & 0.22 & 0.21 & 0.19 & 0.27 & 0.17 \\
\hline $\mathrm{MgO}$ & 12.97 & 13.75 & 14.52 & 14.89 & 15.26 & 14.95 & 14.24 & 15.18 & 15.57 \\
\hline $\mathrm{CaO}$ & 11.74 & 12.40 & 12.09 & 12.29 & 11.70 & 11.98 & 11.14 & 11.87 & 11.96 \\
\hline $\mathrm{Na} 2 \mathrm{O}$ & 1.43 & 1.58 & 1.22 & 1.32 & 1.35 & 1.39 & 1.38 & 1.20 & 1.22 \\
\hline $\mathrm{K} 2 \mathrm{O}$ & 0.68 & 0.62 & 0.56 & 0.43 & 0.32 & 0.34 & 0.35 & 0.34 & 0.26 \\
\hline $\mathrm{H} 2 \mathrm{O}$ & 2.05 & 2.06 & 2.05 & 2.08 & 2.10 & 2.11 & 2.03 & 2.12 & 2.10 \\
\hline Total & 99.03 & 99.82 & 98.68 & 99.98 & 100.21 & 100.76 & 96.95 & 101.16 & 99.79 \\
\hline \#Si IV & 6.51 & 6.74 & 6.92 & 6.97 & 7.03 & 6.95 & 7.04 & 7.15 & 7.07 \\
\hline \#Al IV & 1.49 & 1.26 & 1.08 & 1.03 & 0.97 & 1.05 & 0.96 & 0.85 & 0.93 \\
\hline T site & 8.00 & 8.00 & 8.00 & 8.00 & 8.00 & 8.00 & 8.00 & 8.00 & 8.00 \\
\hline \#Al VI & 0.59 & 0.48 & 0.38 & 0.37 & 0.36 & 0.50 & 0.47 & 0.33 & 0.40 \\
\hline$\# \mathrm{Fe}+3$ & 0.45 & 0.10 & 0.25 & 0.25 & 0.50 & 0.37 & 0.43 & 0.42 & 0.42 \\
\hline \#Ti & 0.13 & 0.13 & 0.11 & 0.09 & 0.05 & 0.05 & 0.04 & 0.06 & 0.04 \\
\hline$\# \mathrm{Mg}$ & 2.82 & 2.98 & 3.16 & 3.19 & 3.24 & 3.16 & 3.13 & 3.20 & 3.31 \\
\hline$\# \mathrm{Fe}+2$ & 0.99 & 1.29 & 1.07 & 1.08 & 0.82 & 0.90 & 0.91 & 0.96 & 0.81 \\
\hline \#Mn & 0.02 & 0.03 & 0.03 & 0.03 & 0.03 & 0.03 & 0.02 & 0.03 & 0.02 \\
\hline$\# \mathrm{Ca}$ & 0.00 & 0.00 & 0.00 & 0.00 & 0.00 & 0.00 & 0.00 & 0.00 & 0.00 \\
\hline $\mathrm{M} 1,2,3$ & 5.00 & 5.00 & 5.00 & 5.00 & 5.00 & 5.00 & 5.00 & 5.00 & 5.00 \\
\hline$\# \mathrm{Ca}$ & 1.84 & 1.93 & 1.89 & 1.89 & 1.79 & 1.82 & 1.76 & 1.80 & 1.83 \\
\hline $\mathrm{HNa}$ & 0.16 & 0.07 & 0.11 & 0.11 & 0.21 & 0.18 & 0.24 & 0.20 & 0.17 \\
\hline M4 site & 2.00 & 2.00 & 2.00 & 2.00 & 2.00 & 2.00 & 2.00 & 2.00 & 2.00 \\
\hline$\# \mathrm{Ca}$ & 0.00 & 0.00 & 0.00 & 0.00 & 0.00 & 0.00 & 0.00 & 0.00 & 0.00 \\
\hline $\mathrm{\# Na}$ & 0.24 & 0.38 & 0.24 & 0.26 & 0.16 & 0.20 & 0.15 & 0.13 & 0.17 \\
\hline$\# \mathrm{~K}$ & 0.13 & 0.11 & 0.10 & 0.08 & 0.06 & 0.06 & 0.07 & 0.06 & 0.05 \\
\hline A site & 0.37 & 0.49 & 0.34 & 0.34 & 0.22 & 0.26 & 0.22 & 0.19 & 0.21 \\
\hline $\mathrm{HO}$ & 22.00 & 22.00 & 22.00 & 22.00 & 22.00 & 22.00 & 22.00 & 22.00 & 22.00 \\
\hline$\# \mathrm{OH}$ & 2.00 & 2.00 & 2.00 & 2.00 & 2.00 & 2.00 & 2.00 & 2.00 & 2.00 \\
\hline Charge & 0.00 & 0.00 & 0.00 & 0.00 & 0.00 & 0.00 & 0.00 & 0.00 & 0.00 \\
\hline
\end{tabular}



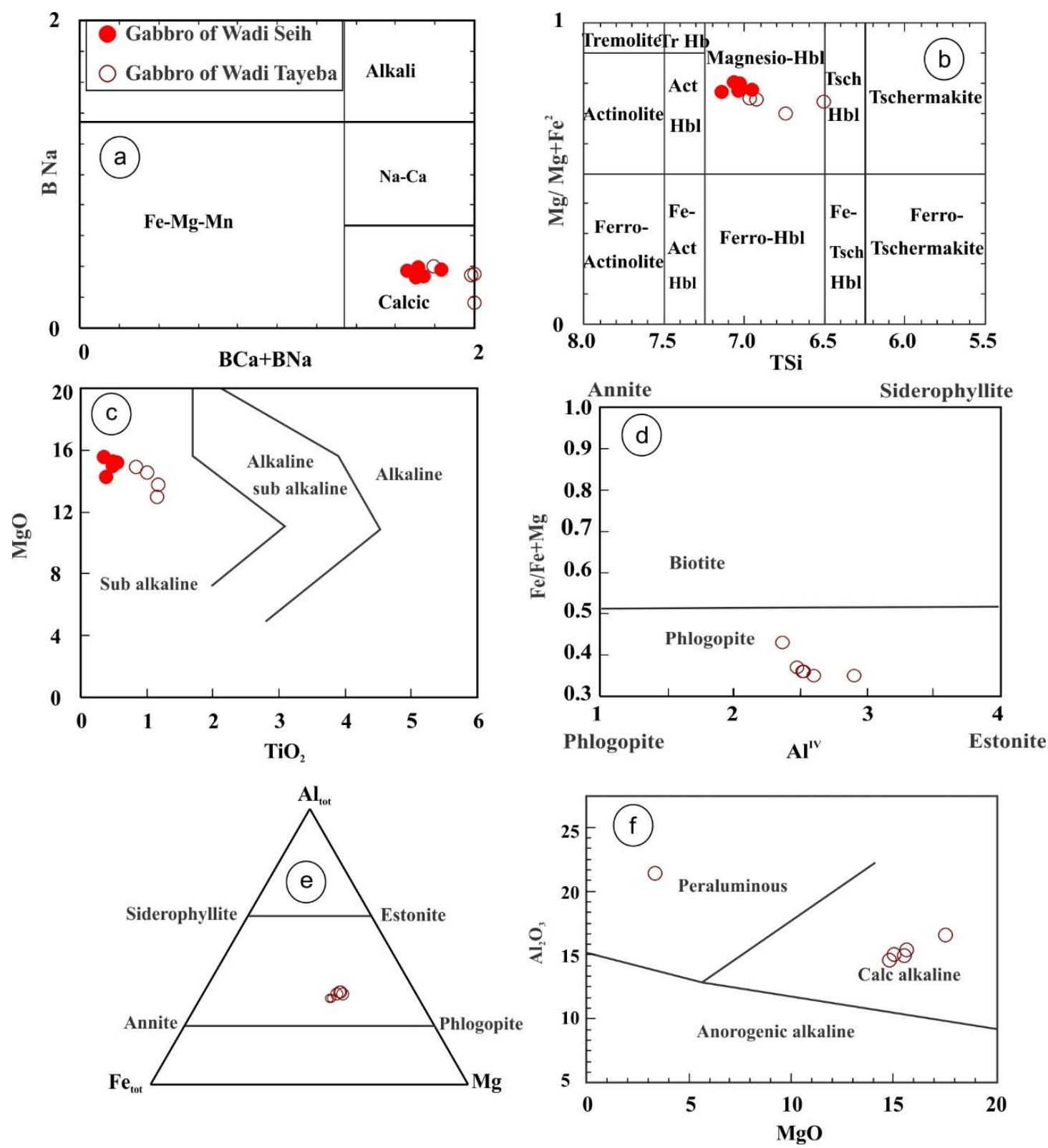

Fig. 5. (a) Plots of $\mathrm{BNa}$ vs. $\mathrm{BCa}+\mathrm{BNa}$ of the present syn-tectonic gabbro after (Leake et al., 1997), (b) Classification diagram of calcic amphibole with $(\mathrm{Na}+\mathrm{K})<.05$ and $\mathrm{Ti}<.05$ (after Leake, 1978), (c) MgO vs. $\mathrm{TiO}_{2}$ diagram (Molina et al., 2009), (d) Fe/(Fe+Mg) vs. Al ${ }^{\mathrm{IV}}$ diagram (after Kubovicz et al., 1989) for biotite nomenclature, (e) Ternary diagram of $\mathrm{MgO}-\mathrm{FeO}_{\text {tot }}-\mathrm{Al}_{2} \mathrm{O}_{3}$ (after De Albuquerque, 1973), (f) MgO$\mathrm{Al}_{2} \mathrm{O}_{3}$ biotite discriminate diagram of the studied syn-tectonic gabbro after (Abdel Rahman,1994).

gabbro Kubovicz et al. (1989), it is evident that samples of syn-tectonic gabbro (E78) lie in the phlogopite field and have a composition between phlogopite and estonite. De Albuquerque (1973) classified the biotites of different mineral associations into the following four fields:- 1) fields of biotites co-existing with amphibole, 2) fields of biotites unaccompanied by ferromagnesian minerals, 3) fields of biotites co-existing with muscovite, and 4) fields of biotites co-existing with aluminosilicates. Plots of biotite of syn-tectonic gabbro fall within field III, except one sample lies in field IV (Fig. 5e). Abdel Rahman (1994) discriminates between alkaline, calcalkaline, and peraluminous nature. Plotting the analyzed biotite of the syn-tectonic gabbro shows that the parent magma has a calc-alkaline nature (Fig. 5f). 
Table 3. Microprobe analyses and structural formulae of biotites.

\begin{tabular}{|c|c|c|c|c|c|c|}
\hline $\begin{array}{l}\text { Analyses/ } \\
\text { Sample No. }\end{array}$ & E78-ime & E78-imf & E78-imc & E78-imd & E78-ima & E78-imb \\
\hline $\mathrm{SiO} 2$ & 37.80 & 36.94 & 41.14 & 32.79 & 36.75 & 35.69 \\
\hline $\mathrm{TiO} 2$ & 2.99 & 2.91 & 0.65 & 2.04 & 2.79 & 5.47 \\
\hline A12O3 & 15.03 & 14.96 & 21.36 & 16.57 & 15.42 & 14.61 \\
\hline $\mathrm{FeO}$ & 14.90 & 15.86 & 4.51 & 16.50 & 15.29 & 15.56 \\
\hline $\mathrm{MnO}$ & 0.11 & 0.11 & 0.03 & 0.09 & 0.09 & 0.09 \\
\hline $\mathrm{MgO}$ & 15.04 & 15.56 & 3.32 & 17.57 & 15.65 & 14.80 \\
\hline $\mathrm{CaO}$ & 0.07 & 0.07 & 21.92 & 0.32 & 0.10 & 0.30 \\
\hline $\mathrm{Na} 2 \mathrm{O}$ & 0.46 & 0.40 & 0.03 & 0.08 & 0.54 & 0.31 \\
\hline $\mathrm{K} 2 \mathrm{O}$ & 9.45 & 8.64 & 0.40 & 4.25 & 8.60 & 8.31 \\
\hline $\mathrm{H} 2 \mathrm{O}$ & 4.04 & 4.03 & 4.29 & 4.09 & 4.04 & 4.03 \\
\hline Total & 99.89 & 99.48 & 97.65 & 94.30 & 99.27 & 99.17 \\
\hline \#Si IV & 5.61 & 5.52 & 5.89 & 5.11 & 5.49 & 5.36 \\
\hline \#Al IV & 2.39 & 2.48 & 2.11 & 2.89 & 2.51 & 2.59 \\
\hline $\mathrm{T}$ site & 8.00 & 8.00 & 8.00 & 8.00 & 8.00 & 8.00 \\
\hline \#A1 VI & 0.24 & 0.15 & 1.50 & 0.16 & 0.20 & 0.00 \\
\hline \#Ti VI & 0.33 & 0.33 & 0.07 & 0.24 & 0.31 & 0.56 \\
\hline$\# \mathrm{Fe}+2$ & 1.85 & 1.98 & 0.54 & 2.15 & 1.91 & 1.95 \\
\hline$\# \mathrm{Mn}+2$ & 0.01 & 0.01 & 0.00 & 0.01 & 0.01 & 0.01 \\
\hline$\# \mathrm{Mg}$ & 3.33 & 3.47 & 0.71 & 4.08 & 3.49 & 3.31 \\
\hline $\mathrm{O}$ site & 5.77 & 5.94 & 2.83 & 6.64 & 5.93 & 5.84 \\
\hline$\# \mathrm{Ca}$ & 0.01 & 0.01 & 3.37 & 0.05 & 0.02 & 0.05 \\
\hline$\# \mathrm{Na}$ & 0.13 & 0.12 & 0.01 & 0.02 & 0.16 & 0.09 \\
\hline$\# \mathrm{~K}$ & 1.79 & 1.65 & 0.07 & 0.85 & 1.64 & 1.59 \\
\hline A site & 1.93 & 1.77 & 3.45 & 0.92 & 1.81 & 1.73 \\
\hline$\# \mathrm{O}$ & 20.00 & 20.00 & 20.00 & 20.00 & 20.00 & 20.00 \\
\hline Charge & 0.00 & 0.00 & 0.00 & 0.00 & 0.00 & 0.00 \\
\hline
\end{tabular}

\subsection{Plagioclase}

Ten single-point analyses of feldspars from two representative samples of syntectonic gabbro (E78, SA3A) have been analyzed and listed in (Table 4). The chemical formula was computed from the obtained analyses on the basis of 32 oxygen atoms. The present data for feldspar are plotted on the Or-Ab-An ternary diagram (Fig. 6a) of Deer et al. (1978). The analyzed samples show that plagioclase from syntectonic gabbro (E78) is plotted in the andesine field. In contrast, plagioclase (SA3A) is plotted in the bytownite field, where it has a high content of $\mathrm{CaO}$ and a medium content of $\mathrm{SiO}_{2}$.

\section{Crystallization conditions (P-T estimate)}

\subsection{Geothermometry}

The formation temperature of the studied syn-tectonic gabbro is obtained by using a ternary composition diagram of feldspar with the solvus isotherms of Elkins and Grove (1990) (Fig. 6b). The investigated plagioclase compositions reveal that the plagioclase from Wadi El Tayeba (E78) was formed around $\left(600^{\circ} \mathrm{C}\right)$ while the other plagioclase from El Seih area (i.e., sample SA3A) was formed around $\left(650^{\circ} \mathrm{C}\right)$.

The $\mathrm{Al}^{\mathrm{IV}}$ of the amphibole is considered as geothermometer and a function of temperature. The temperature of 
Table 4. Microprobe analyses and structural formulae of plagioclase.

\begin{tabular}{|c|c|c|c|c|c|c|c|c|c|}
\hline Sample & $\begin{array}{c}\text { E78- } \\
\text { ipa }\end{array}$ & $\begin{array}{l}\text { E78- } \\
\text { ipb }\end{array}$ & $\begin{array}{l}\text { E78- } \\
\text { ipc }\end{array}$ & $\begin{array}{l}\text { E78- } \\
\text { ipa' }\end{array}$ & $\begin{array}{c}\text { SA3A- } \\
\text { jbp }\end{array}$ & $\begin{array}{c}\text { SA3A- } \\
\text { jpc }\end{array}$ & $\begin{array}{c}\text { SA3A- } \\
\text { jpa }\end{array}$ & $\begin{array}{l}\text { SA3A- } \\
\text { jpe }\end{array}$ & $\begin{array}{c}\text { SA3A- } \\
\text { jpf }\end{array}$ \\
\hline Core/rim & $\mathrm{c}$ & $\mathrm{r}$ & $\mathrm{c}$ & $\mathrm{c}$ & $\mathrm{r}$ & $\mathrm{c}$ & $\mathrm{c}$ & $\mathrm{c}$ & $\mathrm{r}$ \\
\hline $\mathrm{SiO} 2$ & 61.53 & 61.96 & 61.95 & 60.02 & 47.19 & 47.24 & 46.73 & 49.41 & 47.48 \\
\hline $\mathrm{A} 12 \mathrm{O} 3$ & 25.40 & 24.78 & 24.25 & 25.01 & 32.14 & 31.94 & 34.71 & 31.84 & 31.85 \\
\hline $\mathrm{Fe} 2 \mathrm{O} 3$ & 0.08 & 0.10 & 0.09 & 0.04 & 0.23 & 0.12 & 0.13 & 0.12 & 0.13 \\
\hline $\mathrm{MgO}$ & 0.02 & 0.03 & 0.02 & 0.03 & 0.05 & 0.03 & 0.03 & 0.03 & 0.02 \\
\hline $\mathrm{MnO}$ & 0.02 & 0.02 & 0.03 & 0.02 & 0.00 & 0.03 & 0.02 & 0.00 & 0.00 \\
\hline $\mathrm{CaO}$ & 7.10 & 6.64 & 6.43 & 7.23 & 16.82 & 16.41 & 17.56 & 16.28 & 16.22 \\
\hline $\mathrm{Na} 2 \mathrm{O}$ & 7.15 & 7.83 & 7.84 & 8.12 & 2.18 & 2.20 & 1.38 & 2.56 & 2.36 \\
\hline $\mathrm{K} 2 \mathrm{O}$ & 0.11 & 0.10 & 0.09 & 0.14 & 0.01 & 0.01 & 0.01 & 0.01 & 0.00 \\
\hline Total & 101.41 & 101.46 & 100.70 & 100.61 & 98.62 & 97.98 & 100.57 & 100.25 & 98.06 \\
\hline$\# \mathrm{Si}+4$ & 2.69 & 2.71 & 2.73 & 2.67 & 2.20 & 2.21 & 2.13 & 2.26 & 2.22 \\
\hline$\# \mathrm{Al}+3$ & 1.31 & 1.28 & 1.26 & 1.31 & 1.77 & 1.76 & 1.87 & 1.71 & 1.75 \\
\hline$\# \mathrm{Fe}+3$ & 0.00 & 0.00 & 0.00 & 0.00 & 0.01 & 0.00 & 0.00 & 0.00 & 0.00 \\
\hline$\# \mathrm{Mg}+2$ & 0.00 & 0.00 & 0.00 & 0.00 & 0.00 & 0.00 & 0.00 & 0.00 & 0.00 \\
\hline$\# \mathrm{Mn}+2$ & 0.00 & 0.00 & 0.00 & 0.00 & 0.00 & 0.00 & 0.00 & 0.00 & 0.00 \\
\hline$\# \mathrm{Ca}+2$ & 0.33 & 0.31 & 0.30 & 0.34 & 0.84 & 0.82 & 0.86 & 0.80 & 0.81 \\
\hline $\mathrm{HNa}+1$ & 0.61 & 0.66 & 0.67 & 0.70 & 0.20 & 0.20 & 0.12 & 0.23 & 0.21 \\
\hline$\# \mathrm{~K}+1$ & 0.01 & 0.01 & 0.01 & 0.01 & 0.00 & 0.00 & 0.00 & 0.00 & 0.00 \\
\hline \#Total & 4.96 & 4.98 & 4.98 & 5.03 & 5.01 & 5.01 & 4.99 & 5.00 & 5.01 \\
\hline \#O-2 & 8.00 & 8.00 & 8.00 & 8.00 & 8.00 & 8.00 & 8.00 & 8.00 & 8.00 \\
\hline $\mathrm{Na}+\mathrm{K}+\mathrm{Ca}$ & 0.95 & 0.98 & 0.98 & 1.05 & 1.04 & 1.02 & 0.98 & 1.02 & 1.03 \\
\hline $\mathrm{Ab}$ & 0.64 & 0.68 & 0.68 & 0.67 & 0.19 & 0.20 & 0.12 & 0.22 & 0.21 \\
\hline Or & 0.01 & 0.01 & 0.01 & 0.01 & 0.00 & 0.00 & 0.00 & 0.00 & 0.00 \\
\hline An & 0.35 & 0.32 & 0.31 & 0.33 & 0.81 & 0.80 & 0.87 & 0.78 & 0.79 \\
\hline
\end{tabular}

amphibole formation can be estimated by plotting $\mathrm{Al}^{\mathrm{IV}}$ on the temperature- $\mathrm{Al}^{\mathrm{IV}}$ standard diagram of Blundy and Holland (1990). The diagram reveals that the amphiboles of syn-tectonic gabbro from Seih area (i.e., sample SA3A) indicate a formation temperature in the range of $(610$ ${ }^{\circ} \mathrm{C}-710{ }^{\circ} \mathrm{C}$ ) (Fig. 6c). Ti in hornblende (after Otten, 1984) indicates a formation temperature range of $\left(654^{\circ} \mathrm{C}-699^{\circ} \mathrm{C}\right)$ for E78 and of $\left(590{ }^{\circ} \mathrm{C}-615^{\circ} \mathrm{C}\right)$ for SA3A.

The chemistry of the co-existing amphibole and plagioclase pairs is plotted on the diagram of Perchuk (1970) and yields an approximate temperature ranging of (650$700{ }^{\circ} \mathrm{C}$ ) except one sample from Seih area (SA3A) and of (500-550 $\left.{ }^{\circ} \mathrm{C}\right)$ for gabbro in Wadi Tayeba (sample E78) (Fig 6d). The amphibole-plagioclase pairs indicate a temperature range of $\left(626-691{ }^{\circ} \mathrm{C}\right)$ based on Schmidt, 1992 for gabbro of Wadi Tayeba (E78).

\subsection{Geobarometry}

The pressure of syn-tectonic gabbro was calculated by applying the geobarometer equations proposed by (Hammarstrom and Zen, 1986), (Hollister et al., 1987), (Johnson and Rutherford, 1989), and (Schmidt, 1992) using Al in amphiboles as barometers. From the four Al-barometers, the pressure was calculated using the average of the four equations, which is about $(4.4 \mathrm{~kb})$ and the depth of emplacement is about $14.5 \mathrm{~km}$ for syn-tectonic gabbros in Wadi Tayeba (sample E78) and about (2.9 $\mathrm{kb}$ ) for syn-tectonic gabbros from Wadi Seih (SA3A) with a depth of about $9.57 \mathrm{~km}$. Ti versus $\mathrm{Al}^{\text {tot }}$ of the studied amphibole (after Hynes, 1982) (Fig. 6e) indicates that the (SA3A) was formed under medium pressure conditions, while sample (E78) shows lowpressure conditions. $\mathrm{Al}^{\text {tot }}$ vs. Na diagram of Brown (1977) suggests a pressure range of (4-6 kb) for sample (E78) and (5-6 kb) for sample SA3A (Fig. 6f). 

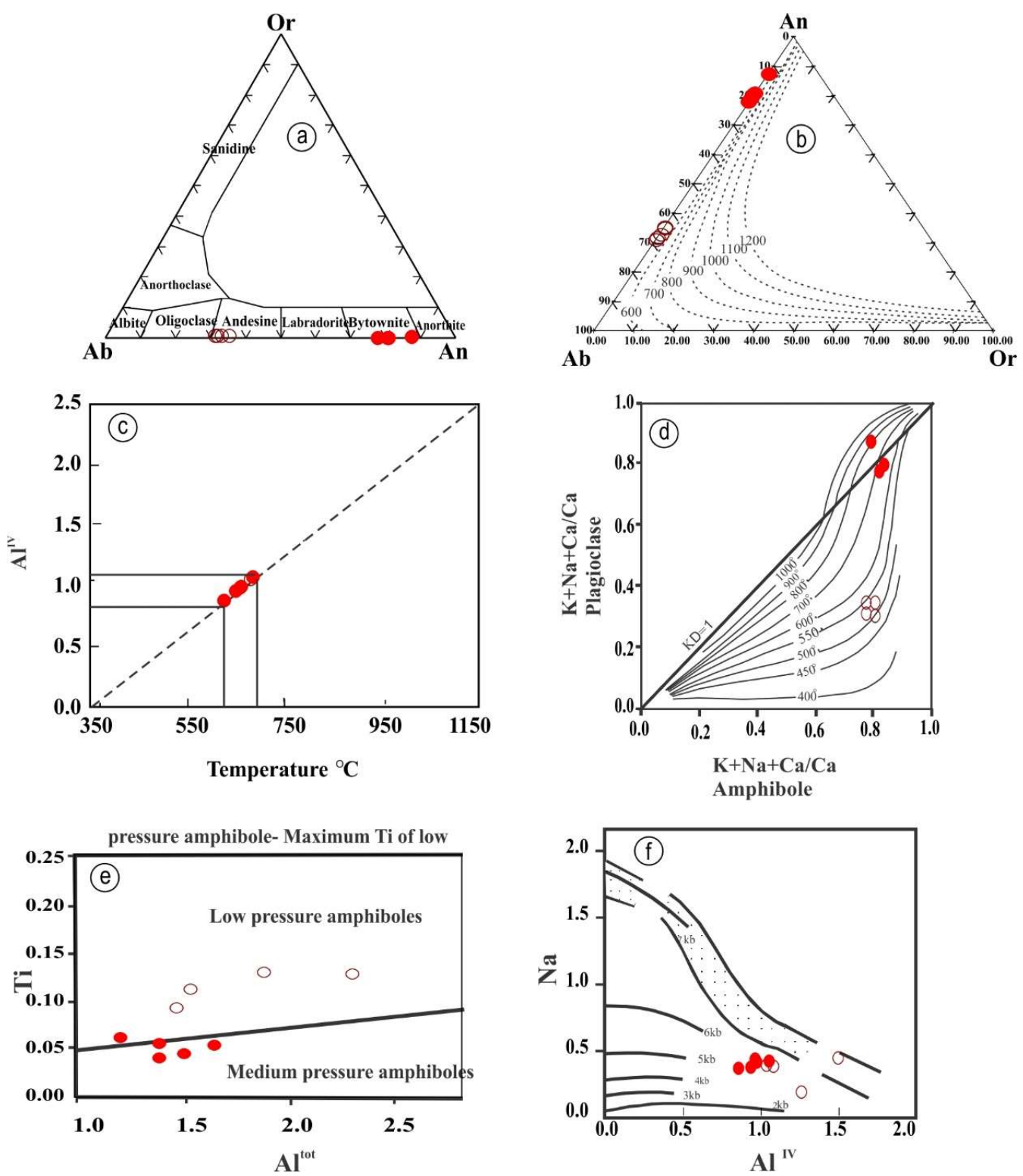

Fig. 6. (a) Or-Ab-An ternary diagram of plagioclase composition of the studied gabbro (after Deer et al., 1978), (b) Ternary composition diagram for feldspar with the solvus isotherms of Elkins and Grove (1990) (c) Temperature-Al ${ }^{\mathrm{IV}}$ diagram (after Blundy and Holland, 1990), (d) Amphibole-plagioclase pairs of the studied syn-tectonic gabbro in the distribution diagram given by Perchuk (1970), (e) Plots of $\mathrm{Al}^{\text {tot }}$ vs. Ti for the studied amphiboles (after Hynes, 1982), and (f) Plots of $\mathrm{Al}^{\mathrm{IV}}$ against BNa of the studied amphiboles (after Brown, 1977).

\section{Summary and tectonic evolution}

The present study revealed the following characteristics:

1. There is no evidence for folding, deformation, and metamorphism, which indicates that the present gabbros are related to late to syn-tectonic stage of the Pan-African orogeny and are not related to the ophiolite suite.
2. The present gabbroic intrusion displays characteristics of a tholeiitic affinity magma type with minor calc-alkaline in transitional from arc stage at the plate margin to continental magmatism and intruded into the continental crust derived from a mantle source strongly modified by fluids related to subduction of an oceanic slab, as suggested by Essawy et al. (1997). 


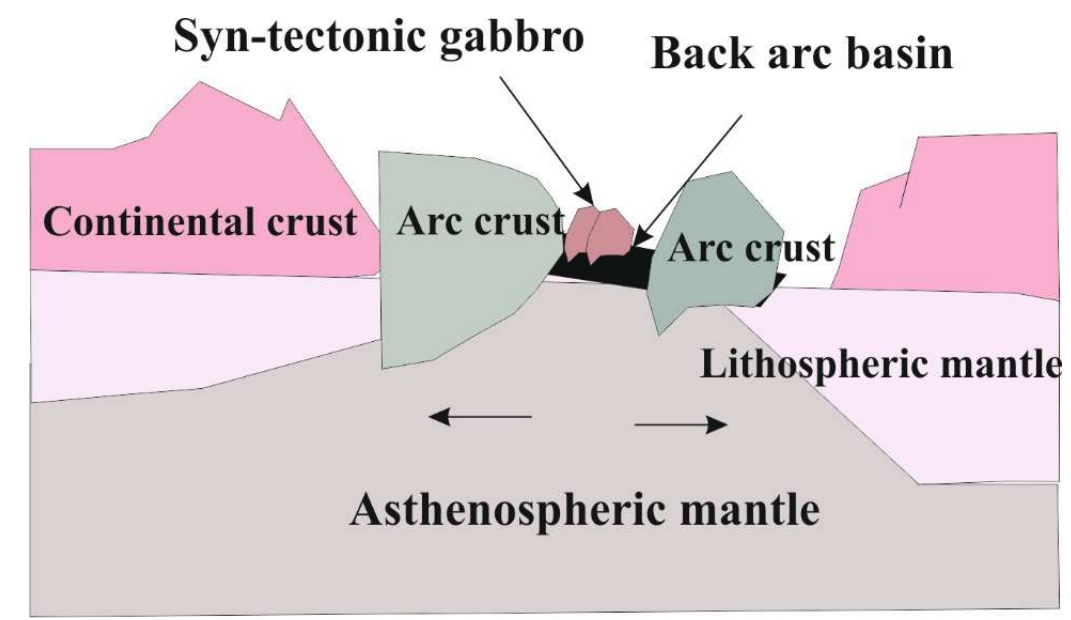

Fig. 7. A proposed schematic diagram for tectonic evolution of syn-tectonic gabbro.

3. Microprobe data of amphiboles indicate that the amphiboles are classified as magnesio-hornblende, whereas biotite lies in the phlogopite field and has a composition between phlogopite and estonite. Plagioclase varies in composition from andesine to bytownite in the present gabbros. The presence of hornblende as a separate crystal reflects that the present gabbros derived from hydrous magma, most probably as a result of the introduction of water into the gabbro during a metamorphic event that occurred early and formed gneisses in the present area.

4. The Seih gabbro was formed at a temperature range of $590{ }^{\circ} \mathrm{C}$ to $700{ }^{\circ} \mathrm{C}$ and a pressure of between 2.9 and $4.4 \mathrm{~kb}$, as indicated by many geothermometers and geobarometers.

5. The tectonic evolution proposed for the syn-tectonic gabbros in Seih area is as follows: After the arc - arc collision stage at $\sim 617 \mathrm{Ma}$ (i.e., the Ediacaran age) (Abu Anbar, 2009), the northern part of the Arabian-Nubian Shield was subjected to an extension regime that formed a series of back-arc basins (Hassan et al., 2020; Abu-Alam et al., in print). At this stage, syn-tectonic gabbro formed with a chemical signature of tholeiitic to calc- alkaline nature, indicating MORB affinity. This magma intruded shallower crustal level rocks and crystallized at a temperature range of $\left(550-710^{\circ} \mathrm{C}\right)$ and pressure (3-4.4 $\mathrm{kb})$ at a depth of emplacement of (10-14.5 km) (Fig. 7).

\section{Acknowledgments}

We would like to express our sincere thanks to Prof. R. Kryza, Institute of Geological Sciences, Wroclaw University, Poland, for microprobe analyses and Grateful thanks are also to Prof. Massimo Coltorti, Earth Science Department, Ferrara University, Italy, for analyze major and trace elements. Thanks to Dr. Tamer Abu-Alam, UIT the Arctic University of Norway for his constructive criticism of this manuscript. Constructive comments from two anonymous reviewers and the final revision from Prof. Yehya AbdelGelel are highly appreciated. We wish to thank associate Editor and Editor for their editorial efforts.

\section{References}

Abdel-Karim, A. A. M., 2013: Petrology, geochemistry and petrogenetic aspects of Younger gabbros from south Sinai: A transition from arc to active continental margin. Geochemistry, 73(1), 89-104. 
Abdel-Karim, A.M., 1995: Late Precambrian metagabbro-diorite complex from Southwest Sinai, Egypt. Egyptian Journal of Geology, 39, 215 238.

Abu Anbar, M.M., 2009: Petrogenesis of the Nesryin gabbroic intrusion in SW Sinai, Egypt: new contributions from mineralogy, geochemistry, $\mathrm{Nd}$ and $\mathrm{Sr}$ isotopes. Miner. Petrol. 95,87-103.

Basta, F. F., 1998: Mineralogy and petrology of some gabbroic intrusions in Sinai and the Eastern Desert, Egypt. Annals of Geological Survey of Egypt, 21, 239-271.

Belasy, M.R., 1991: Geology, petrography and geochemistry of the metamorphic rocks of Wadi Feiran. Solaf Area. South western Sinai, Egypt. Ph.D. Thesis, Zag. Univ., Zagazig, Egypt. 366pp.

Blundy, J.D, Holland, T. J. B., 1990: Calcic amphibole equilibria and a new amphibole-plagioclase

geothermometer. Contributions to Mineralogy and Petrology, 104, 208224.

Brown, E.H., 1977: The crosstie content of Ca-amphibole as a guide to pressure of metamorphism. Journal of Petrology, $18,35-72$.

Brown, E.H., 1977: The crosstie content of Ca-amphibole as a guide to pressure of metamorphism. Journal of Petrology, $18,35-72$

Cox., K.G., Bell, J.D. and Pankhurst, R.J., 1979: The interpretation of igneous rocks. George Allen and Union, London, $450 \mathrm{pp}$.

De Albuquerque, C.A.R., 1973. Geochemistry of biotites from granitic rocks, Northern Portugal, Geochim. Cosmochim. Acta, 37, 1779-1802.

Deer, W.A., Howie, R.A. and Zussman, J., 1978: Rock-forming minerals. 2A, single chain silicates. Longman, London, $668 \mathrm{P}$.

EGSMA (Egyptian Geological Survey and Mining Authority) 1981: Geologic map of Egypt. Scale 1:200,000. Egypt. Cairo, 1 map.
Elkins, L. T and Grove, T. L., 1990: Ternary feldspar experiments and thermodynamic models. American Mineralogist 75: 544-559

El-Mettwaly, A., 1992: Pan-African postorogenic gabbro cumulates from Sinai massif, Egypt: Geochemistry and mineral chemistry. Journal of African Earth Sciences, 14, 217-235.

El-Metwally, A.A., 1986: Mafic and ultramafic rocks north of Wadi Feiran, southern Sinai, Egypt. Ph.D. Thesis, Mansoura Univ., Mansoura, Egypt. $185 \mathrm{pp}$.

El-Sheshtawy, Y. A.,1984: Petrographical and geochemical studies of granitic rocks around Wadi El-Sheikh, southwest Sinai, Egypt. Ph.D. Thesis, Al-Azhar Univ. Cairo, Egypt. 213pp.

El-Tokhi, M. M. and Katta, L. A., 1993: Geochemistry, mineral chemistry and petrogenetic evolution of intrusive gabbro-diorite complex, SW Sinai, Egypt. Egypt Mineral, 5, 81-103.

El-Tokhi, M., 1990: Petrographical, geochemical and experimental studies on the migmatite rocks of Wadi Feiran, S. Sinai, Egypt. Ph.D. Thesis, Karlsruhe Univ., Germany, 98p.

Essawy, M. A., El-Metwally, A. A. and Althaus, E., 1997: A Pan African layered mafic-ultramafic cumulate complex in the SW Sinai massif: Mineralogy, geochemistry and crustal growth. Chemie Der ErdeGeochemistry, 57 (2-3), 137-156.

Furnes, H., Shimron, A. E., and Roberts, D., 1985: Geochemistry of PanAfrican volcanic arc sequences in southeastern Sinai Peninsula and plate tectonic implications. Precambrian Research, 29(4), 359-382.

Ghoneim, M. F., Aly, S. M., Kaderbi, A. T. and El-Baraga, M., 1991: Geological evolution of the Madsus area, Southeast Sinai. Annals of Geological Survey of Egypt, 17:6771.

Hammarstrom, J. M. and Zen, E. A., 1986: Aluminum in hornblende: an empirical igneous geobarometer. 
American mineralogist, 71(11-12), 1297-1313.

Hassan, M., Abu-Alam, T.S., and Fowler, A.R., 2020: The Sinai Metamorphic Complexes from Rodinia Rifting to the Gondwana Collision. In The Geology of the Egyptian Nubian Shield, Springer, 83-106.

Hassanen, H.A.,1989: Geochemistry and petrogenetic evolution of a Late Precambrian metagabbro-diorite complex, south-eastern Sinai. 1st Conference on Geochemistry. Alex University, Egypt, 118-139.

Higazy, M, El-Gammal, S., 1989: Petrography and geochemistry of the metagabbros from the NW part of the basement rocks in Sinai, Egypt. Annals of Geological Survey of Egypt, XVI:143-147.

Hollister, L. S., Grissom, G. C., Peters, E. K., Stowell, H. H. and Sisson, V. B., 1987: Confirmation of the empirical correlation of $\mathrm{Al}$ in hornblende with pressure of solidification of calcalkaline plutons. American Mineralogist, 72(3-4), 231-239.

Hynes, A., 1982: A Comparison of amphiboles from medium and low pressure metabasiltes Contributions to Mineralogy and Petrology, 81, 110125.

Irvine, T. N. and Baragar, W. R. A., 1971: A guide to the chemical classification of the common volcanic rocks. Canadian journal of earth sciences, 8 (5), 523-548.

Johnson, M. C. and Rutherford, M. J., 1989: Experimental calibration of the aluminum-in-hornblende

geobarometer with application to Long Valley caldera (California) volcanic rocks. Geology, 17(9), 837841.

Kubovics, I., Szabó, C. S. and Solymos, K., 1989: Geochemistry of phlogopites in ultramafix xenoliths of lamprophyre dykes (Alcsutdoboz, Hungary). Neues Jahrbuch für Mineralogie. Abhandlungen, 161(2), 171-191.
Kuno, H., 1968: Origin of andesite and its bearing on the island arc structure. Bulletin Volcanologique, 32(1), 141176.

Lachance, G. and Traill, R., 1966: The theoretical influence coefficient method. Spectrosc, 11, 43-48.

Leake, B. E., 1978: Nomenclature of amphiboles. American Mineralogist, 63(11-12), 1023-1052.

Leake, B. E., Woolley, A. R., Arps, C. E. S., Birch, W. D., Gilbert, M. C., and Grice, J. D., 1997: Nomenclature of amphiboles: report of the subcommittee on amphiboles of the international mineralogical association, commission on new minerals and mineral names. American Mineralogistal, 82, 1019-1037.

Lebda, E. M., Ghoneim, M. F. and AbdelKarim, A. A., 2019: Gabbros versus granites of the subduction regime of South Sinai, Egypt: discrimination and geochemical modelling. Arabian Journal of Geosciences, 12(17), 1-24.

Madbouli, M.E., 1991: Petrology and geochemistry of some mafic and ultramafic rocks of Sinai, Egypt. M.Sc. Thesis, Cairo University, Egypt.

Mehanna, A.M. and Soliman, F.A., 2000: Geology and geochemistry of the syntectonic metagabbro-diorite complex of Wadi El-Gofa, southwest Sinai, Egypt., Egypt. Journal of Geology, 44/2, 61-77.

Middlemost, E. A. k., 1985: Magma and magmatic rocks, an introduction to igneous petrology: Longman Inc., New York, 257p.

Miyashiro, A., 1975: Volcanic rock series and tectonic setting. Annual Review of Earth and Planetary Sciences, 3(1), 251-269.

Molina, J. F, Scarrow, J. H, Montero, P.G. and Bea, F., 2009: High-Ti amphibole as a petrogenetic indicator of magma chemistry: evidence for mildly alkalic-hybrid melts during evolution of Variscan basic-ultrabasic magmatism of Central Iberia. Contribution to Minerology and Petrology, 158:69-98. 
Pearce, T. H., Gorman, B. E. and Birkett, T. C., 1977: The relationship between major element chemistry and tectonic environment of basic and intermediate volcanic rocks. Earth and Planetary Science Letters, 36(1), 121-132.

Perchuk, L.L., 1970: Equilibria OJ RockForming Minerals, 301 'Nauka' Press, Moscow, 301pp.

Rock, N. M. S. and Leake, B. E., 1984: The International Mineralogical Association amphibole nomenclature scheme: computerization and its consequences. Mineralogical Magazine, 48(347), 211-227.

Ross, P. S. and Bédard, J. H., 2009: Magmatic affinity of modern and ancient subalkaline volcanic rocks determined from trace-element discriminant diagrams. Canadian
Journal of Earth Sciences, 46(11), 823-839.

Schmidt, M. W., 1992: Amphibole composition in tonalite as a function of pressure: an experimental calibration of the Al-in-hornblende barometer. Contributions to mineralogy and petrology, 110 (2), 304-310.

Sun, S. S. and McDonough, W. F., 1989: Chemical and isotopic systematics of oceanic basalts: implications for mantle composition and processes. Geological Society, London, Special Publications, 42(1), 313-345.

Takla, M.A., Basta, F.F., Madbouly, M.I. and Hussein, A.A., 2001: The maficultramafic intrusions of Sinai, Egypt. Annals of Geological Survey of Egypt, 24, 1-40.

Wilson, M., 1989: Igneous Petrogenesis. Chapman and Hill, London. 466p.

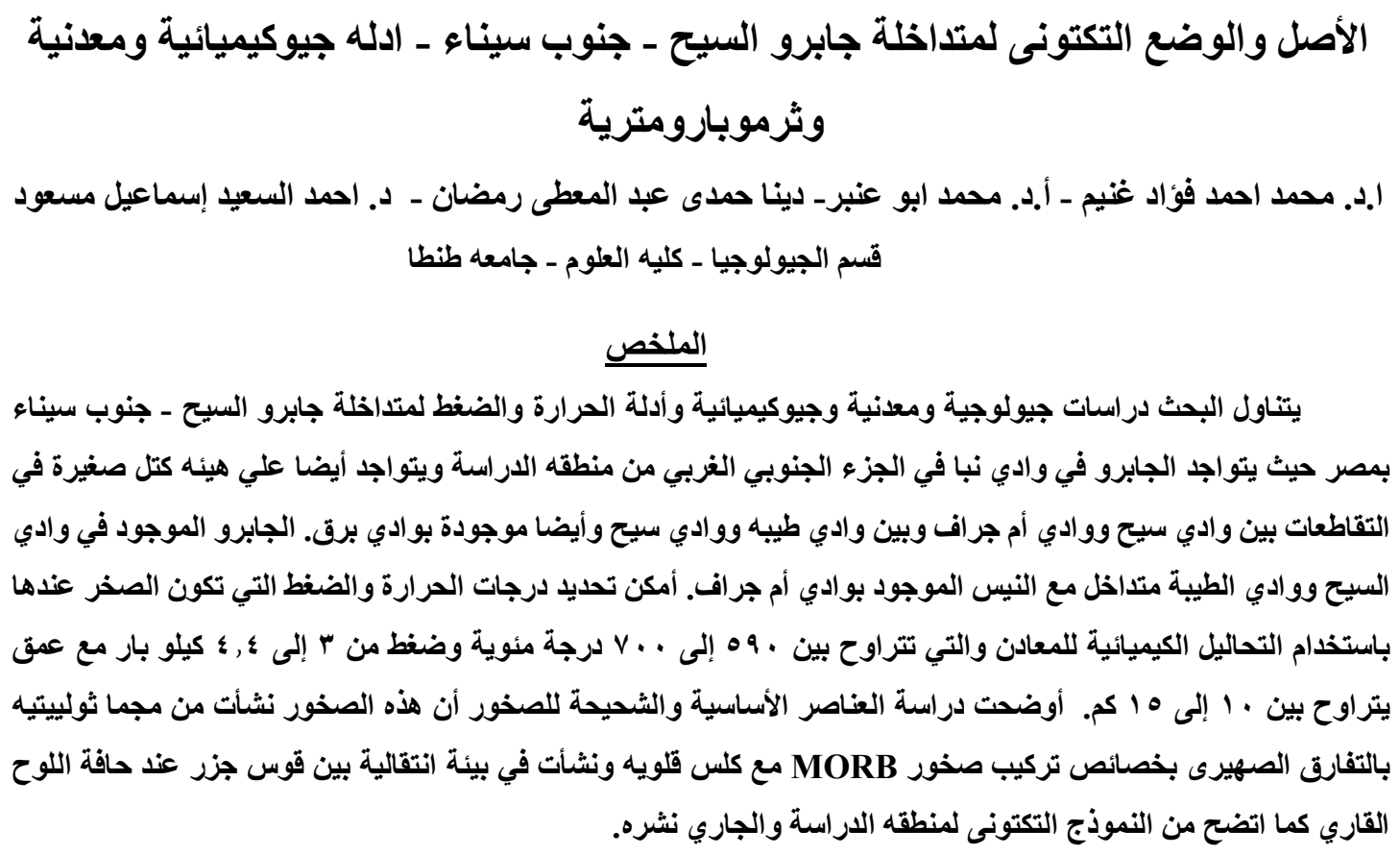

